Vol. 5. No.1, April, 2017: 95-113, ISSN (cet): 2355-1755 | ISSN (online): 2579-6437

\title{
ANALISIS TRANSAKSI RESI GUDANG DAN POTENSI PENGEMBANGANNYA KE UNIT SYARIAH
}

\section{Lutfi Zulkarnain ${ }^{1}$}

${ }^{1}$ Afiliasi: Sekolah Tinggi Ekonomi Islam SEBI. Email: lutfizulkarnain@gmail.com

\begin{abstract}
ABSTRAK. Indonesia merupakan negara agraris dan sebagian besar penduduknya bekerja sebagai petani dan pengusaha agribisnis. Masalah yang sering dihadapi oleh petani atau pengusaha agribisnis dalam mengembangkan bisnis adalah masalah modal. Harga komoditi berjangka jatuh saat panen, petani tidak punya pilihan selain untuk menjual barang komoditas ke tengkulak. Sistem Resi Gudang lahir untuk memenuhi kebutuhan petani dalam mendanai untuk membeli keperluan musim tanam berikutnya. Dengan sistem resi gudang, petani dapat memastikan barang komoditi yang disimpan di gudang mendapatkan pinjaman dari bank atau lembaga keuangan dan kemudian menjual kembali saat harga mulai membaik. Penelitian ini dilakukan untuk mendapatkan jawaban tentang mekanisme penerbitan, transfer, penyelesaian janji, dan resi gudang dan faktor-faktor yang mempengaruhi transaksi resi gudang. Metode penelitian yang digunakan adalah metode deskriptif dengan analisis data kualitatif dan kuantitatif.
\end{abstract}

Kata kunci: Sistem Resi Gudang, Perbankan, Komoditas

ABSTRACT. Indonesia is an agricultural country and most of its residents work as farmers and the agribusiness entrepreneurs. The problem often faced by farmers or agribusiness entrepreneurs in developing a business is a capital problem. Future commodity prices fall harvest, farmers have no choice but to sell commodity goods to middlemen. Warehouse Receipt System was born to meet the needs of farmers will be funding to buy the purposes of the next planting season. With a warehouse receipt system, farmers can ensure a commodity item that is stored in the warehouse to get a loan from banks or financial institutions for commodity goods and then resell when prices began to improve. This study was conducted to get answers about the publishing mechanisms, transfer, pledge, and warehouse receipts settlement and the factors that affect the warehouse receipt transactions. The research method used is descriptive method with qualitative and quantitative data analysis.

Keywords: Warehouse Receipt System, Banking, commodity

\section{PENDAHULUAN}

Sistem pembiayaan perdagangan sangat diperlukan bagi dunia usaha untuk menjamin kelancaran usahanya terutama bagi usaha kecil dan menengah, termasuk petani yang umumnya menghadapi masalah pembiayaan karena keterbatasan akses dan jaminan kredit. Sistem Resi Gudang merupakan salah satu instrumen penting dalam sistem pembiayaan perdagangan. Sistem Resi Gudang dapat memfasilitasi pemberian kredit bagi dunia usaha dengan agunan inventori atau barang yang disimpan di gudang. Sistem Resi Gudang juga membantu petani menjual gabah pada harga yang lebih tinggi. Hal itu 
karena pada harga jual gabah yang semakin tinggi, maka penerimaan petani meningkat. Di samping itu, Sistem Resi Gudang dapat digunakan oleh pemerintah untuk persediaan nasional.

Salah satu upaya yang dilakukan pemerintah dalam memberikan pelayanan kepada dunia usaha adalah pengimplementasian Undang-Undang Nomor 9 Tahun 2006 tentang Sistem Resi Gudang (SRG), yang merupakan payung hukum dalam memberikan akses bagi Usaha Kecil dan Menengah (UKM) maupun petani untuk mendapatkan pinjaman atau permodalan dari Bank Lembaga Keuangan Non Bank. Dan saat ini sudah disempurnakan berdasarkan Undang-Undang Nomor 9 Tahun 2011 tentang perubahan Sistem Resi Gudang.

Sistem resi gudang adalah kegiatan yang berkaitan dengan penerbitan, pengalihan, penjaminan, dan penyelesaian resi gudang (Pasal 1 angka $1 \mathrm{UU}$ Resi Gudang). Resi gudang sendiri adalah dokumen bukti kepemilikan atas barang yang disimpan di gudang yang diterbitkan oleh pengelola gudang. (Kementerian Perdagangan Republik Indonesia 2009)

Melalui Resi Gudang, akses untuk memperoleh pembiayaan dengan mekanisme yang sederhana dapat diperoleh petani serta usaha kecil dan menengah yang berbasis pertanian. Kata kunci dari Sistem Resi Gudang adalah kelaikan gudang (warehouse ability). Diharapkan dengan Sistem Resi Gudang ini dapat meningkatkan produktivitas dan kualitas produk yang dihasilkan para petani, serta menetapkan strategi jadwal tanam dan pemasarannya.

Setelah diundangkannya Undang-Undang Nomor 9 Tahun 2006 tentang Sistem Resi Gudang pada tanggal 14 Juli 2006 dan Peraturan Pemerintah Nomor 36 Tahun 2007 tentang Pelaksanaan Undang-Undang Nomor 9 Tahun 2006 tentang Sistem Resi Gudang pada tanggal 22 Juni 2007, Sistem Resi Gudang di Indonesia diharapkan dapat berjalan dengan baik dan meningkat dengan cepat. Namun, dalam perkembangannya terdapat beberapa kelemahan di lapangan yang sangat menghambat perkembangan Resi Gudang, di antaranya adalah dengan tidak tersedianya mekanisme jaminan yang relatif terjangkau bagi pelaku usaha apabila Pengelola Gudang mengalami pailit atau melakukan kelalaian dalam pengelolaan (mishandling) sehingga tidak dapat melaksanakan kewajibannya mengembalikan barang yang disimpan di gudang sesuai dengan kualitas dan kuantitas yang tertera dalam Resi Gudang.

Hipotesis pada penelitian ini adalah apakah Sistem Resi Gudang akan mensejahterakan petani?, dan manakah yang lebih sejahtera petani kecil, petani besar atau pedagang (tengkulak)?. Fakta yang terjadi adalah petani berkelompok untuk memenuhi skala ekonomi. Apakah jika sudah berkelompok dapat memperbanyak transaksi Sistem Resi Gudang?. Dan apakah setelah berkelompok itu suatu hari bisa menambah luas lahan? Atau justru petani terlibat dalam kredit yang lebih memiskinkan mereka?

Untuk berupaya menjawab hipotesa besarnya maka akan kami kemukakan Faktor-faktor yang bisa memperbesar transaksi resi gudang 
Jurnal Ekonomi dan Perbankan Syariah

Vol. 5. No.1, April 2017: 95-113, ISSN (cet): 2355-1755 | ISSN (online): 2579-6437

sehingga petani diharapkan akan meningkat tingkat kesejahteraannya antara lain; (Ashari 2011 Volume 29 No.2)

1. Volume produksi gabah yang meningkat.

2. Kebijakan intervensi harga gabah.

3. Teknologi dari masa penyimpanan gabah atau kadar air.

4. Suku bunga atau Riba.

Dengan demikian kita berharap pembiayaan dengan prinsip syariah yang ada pada lembaga-lembaga keuangan syariah, khususnya bank syariah bisa semakin merambah pada bisnis riil yang ada khususnya para petani lewat pembiayaan terhadap Resi Gudang, sehingga kemanfaatannya bisa semakin dirasakan oleh masyarakat secara lebih luas dalam mengembangkan usahanya.

\section{TELAAH TEORITIS}

\subsection{PENGERTIAN RESI GUDANG}

Berdasarkan Undang-undang No. 9 Tahun 2006 tentang Resi Gudang, pengertian Resi Gudang atau juga disebut warehouse receipt adalah dokumen atau surat bukti kepemilikan barang yang disimpan di gudang, yang diterbitkan oleh pengelola gudang tertentu yang harus mendapatkan persetujuan BAPPEBTI. Sistem Resi Gudang merupakan berbagia kegiatan yang berkaitan dengan penerbitan, pengalihan, penjaminan, dan penyelesaian transaksi Resi Gudang.

Sejauh ini telah ada delapan komoditi yang bisa diresigudangkan. Mengacu Peraturan Menteri Perdagangan No. 26/M-DAG/PER/6/2007 tentang barang yang dapat disimpan di Gudang Dalam Penyelenggaraan Sistem Resi Gudang, komoditi tersebut adalah: gabah, beras, jagung, kopi, kakao, lada, karet, dan rumput laut.

Dalam SRG, komoditi harus memiliki persyaratan seperti: mempunyai usia simpan yang cukup lama, minimal 3 bulan; harganya berfluktuasi, yakni rendah saat musim panen, dan tinggi saat musim tanam atau paceklik; mempunyai standar mutu tertentu; serta komoditi potensial dan sangat berperan dalam perekonomian daerah setempat dan nasional, yang akan menjamin ketahanan pangan nasional serta menjadi unggulan ekspor. (Kementerian Perdagangan Republik Indonesia 2011).

\subsection{ALUR SISTEM RESI GUDANG}

Adapun alur penerbitan resi gudang dapat dilihat pada gambar dibawah ini.

Gambar 1. Alur Penerbitan Resi Gudang 


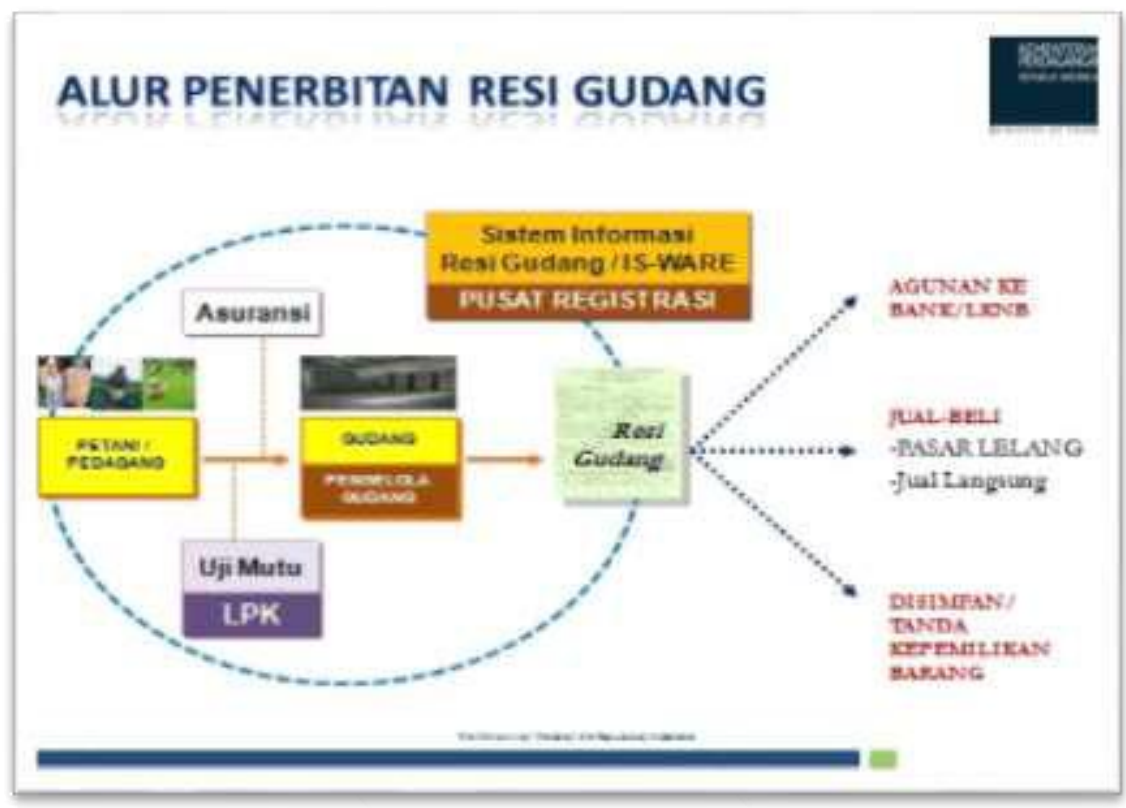

Sumber : Bappepti Kemendag Republik Indonesia

Untuk mendapatkan Resi Gudang petani terlebih dahulu mendatangi Pengelola Gudang dengan membawa komoditi yang akan diresigudangkan. Sebelum masuk gudang, komoditi tersebut terlebih dahulu diuji mutu dan kuantitasnya oleh LPK yang ada di Gudang atau Kantor Pengelola Gudang.

Sementara itu Pengelola Gudang akan membuat perjanjian pengelolaan barang yang berisi deskripsi barang dan asuransi. Diskripsi barang dibuat berdasarkan sertifikat hasil uji mutu yang dikeluarkan oleh LPK. Setelah surat perjanjian pengelolaan barang ditandatangani selanjutnya Pengelola Gudang akan menghubungi Pusat Registrasi untuk meminta kode registrasi. Pengelola Gudang dapat langsung menerbitkan Dokumen Resi Gudang tepat setelah menerima kode registrasi dari Pusat Registrasi.

\subsection{FAKTOR-FAKTOR YANG BERHUBUNGAN TERHADAP PELAKSANAAN RESI GUDANG}

Globalisasi ekonomi dunia telah menyebabkan persaingan yang semakin ketat dan perubahan yang sangat cepat, yang menuntut dunia usaha dan pemerintah agar lebih responsif dalam melakukan berbagai upaya penyempurnaan terhadap terciptanya iklim usaha yang kondusif dan dapat memberikan kontribusi dalam perekonomian Indonesia.

Pesatnya perkembangan ekonomi dunia tentunya sangat mempengaruhi naik turunnya laju pertumbuhan ekonomi nasional terutama di bidang produksi, pendistribusian dan pemasaran barang atau komoditi, sehingga menuntut adanya 
Jurnal Ekonomi dan Perbankan Syariah

Vol. 5. No.1, April 2017: 95-113, ISSN (cet): 2355-1755 | ISSN (online): 2579-6437

101

Suatu instrumen yang dapat menjadi alternatif solusi pembiayaan di saat harga-harga komoditi mengalami penurunan drastis. Banyak sekali faktor-faktor yang berpengaruh terhadap transaksi Resi Gudang, namun ada beberapa yang akan dibahas dengan seksama antara lain: volume produksi gabah, harga gabah, teknologi masa penyimpanan gabah, dan perkembangan suku bunga kredit. (Ashari 2011 Volume 29 No.2 )

\subsection{TINJAUAN SYARIAH TERHADAP SISTEM RESI GUDANG}

Dari latar belakang masalah dan manfaat yang didapatkan dalam Sistem Resi Gudang di atas ternyata banyak yang bersesuaian dengan prinsip-prinsip ekonomi Islam. Mayoritas penduduk negeri ini berprofesi menjadi petani, maka wajar kalau Indonesia ini dinamakan sebagai negara agraris-tradisional. Sektor pertanian menjadi sektor yang sangat menentukan nasib jutaan penduduk. Kalau kondisi pertanian mengalami kemajuan dan perkembangan, maka tingkat kesejahteraan penduduk akan naik, namun jika sebaliknya, maka mereka akan terus dalam kemiskinan dan keterbelakangan, selalu menjadi obyek eksploitasi pihak-pihak tertentu. Karena itu pemerintah membangun Sistem Resi Gudang.

Hal ini bersesuaian dengan kaidah fiqh yang berbunyi: "Tashorruful imam ala al-roiyyati manuthun bil maslahah". Artinya, kebijakan penguasa kepada rakyatnya harus diarahkan untuk kemaslahatan (kemajuan dan pengembangan).

Tabel 1. Ringkasan Analisis Tinjauan Ilmu Fiqh

\begin{tabular}{|c|c|c|}
\hline No & $\begin{array}{l}\text { Latar Belakang dan Manfaat } \\
\text { Sistem Resi Gudang }\end{array}$ & $\begin{array}{c}\text { Kesesuaiannya dengan prespektif } \\
\text { Islam }\end{array}$ \\
\hline 1 & $\begin{array}{l}\text { Salah satu tujuan pembangunan } \\
\text { nasional adalah mewujudkan } \\
\text { masyarakat adil dan makmur } \\
\text { berdasarkan Pancasila dan } \\
\text { Undang-Undang Dasar Negara } \\
\text { Republik Indonesia Tahun } 1945 \\
\text { dalam wadah Negara Kesatuan } \\
\text { Republik Indonesia yang } \\
\text { merdeka, bersatu, dan } \\
\text { berkedaulatan rakyat dalam } \\
\text { suasana perikehidupan bangsa } \\
\text { yang aman, tenteram, tertib, dan } \\
\text { dinamis. }\end{array}$ & $\begin{array}{l}\text { Semua yang melatarbelakangi } \\
\text { dibuatnya regulasi Sistem Resi } \\
\text { Gudang ternyata bersesuaian } \\
\text { dengan nilai-nilai universal } \\
\text { prinsip ekonomi Islam yang } \\
\text { sudah dijelaskan diatas, antara } \\
\text { lain: } \\
\text { Prinsip Kerja } \\
\text { Prinsip Kompensasi } \\
\text { Prinsip Effisiensi } \\
\text { Prinsip Profesionalisme } \\
\text { Prinsip Kecukupan } \\
\text { Prinsip Pemerataan Kesempatan } \\
\text { Prinsip Kebebasan } \\
\text { Prinsip Kerja Sama }\end{array}$ \\
\hline
\end{tabular}


102 | Zulkarnain: Analisis Transaksi Resi Gudang dan Potensi Pengembangannya...
Prinsip Persaingan
Prinsip Keseimbangan
Prinsip Solidaritas
Prinsip Informasi Simetri

\begin{tabular}{|c|c|c|}
\hline 2 & $\begin{array}{l}\text { Diperlukan instrumen dalam } \\
\text { penataan sistem perdagangan } \\
\text { yang efektif dan efisien, } \\
\text { sehingga harga barang yang } \\
\text { ditawarkan dapat bersaing di } \\
\text { pasar global. }\end{array}$ & $\begin{array}{l}\text { Tidak } \\
\text { persyaratannya ihtikar yaitu, } \\
\text { mengupayakan } \\
\text { kelangkaan barang baik dengan } \\
\text { cara menimbun stock atau } \\
\text { mengenakan entry barriers. } \\
\text { Kemudian menjual dengan harga } \\
\text { tinggi dibandingkan harga } \\
\text { sebelum munculnya kelangkaan. } \\
\text { Justru Sistem Resi Gudang } \\
\text { berupaya untuk melindungi para } \\
\text { petani dari kerugian yang } \\
\text { seringkali terjadi saat panen tiba } \\
\text { dan saat akan menanam kembali }\end{array}$ \\
\hline 3 & $\begin{array}{l}\text { Sistem pembiayaan perdagangan } \\
\text { sangat diperlukan bagi dunia } \\
\text { usaha untuk menjamin } \\
\text { kelancaran usahanya terutama } \\
\text { bagi usaha kecil dan menengah, } \\
\text { termasuk petani yang umumnya } \\
\text { menghadapi masalah } \\
\text { pembiayaan, karena keterbatasan } \\
\text { akses dan jaminan kredit }\end{array}$ & $\begin{array}{l}\text { Berdasarkan kaidah fiqih yang } \\
\text { mengatakan: } \\
\text { "Hak orang lain terpelihara } \\
\text { menurut syara". Maka baik } \\
\text { produsen maupun konsumen hak } \\
\text { mereka haruslah terpelihara, } \\
\text { sehingga tidak saling menzalimi } \\
\text { satu sama lain dan untuk itu } \\
\text { dibutuhkan peran pemerintah } \\
\text { dalam mengaturnya. }\end{array}$ \\
\hline
\end{tabular}

Berdasarkan pembahasan di atas, maka dapat disimpulkan bahwa kegiatan menunda penjualan dengan cara menyimpan barang di dalam gudang dengan berbagai latar belakang tersebut di atas, maka Sistem Resi Gudang dapat dikelompokkan bukan termasuk kegiatan ikhtikar. Dengan demikian Sistem Resi Gudang tidak bertentangan dengan ilmu Fiqh, karena Sistem Resi Gudang tidak dimaksudkan untuk menahan barang supaya terjadi kelangkaan. Sistem Resi Gudang mempunyai batas waktu penyimpanan maksimum sekitar 3 bulan hingga 4 bulan dan memungkinkan terjadi kegiatan penjualan yang menghasilkan

\section{METODE PENELITIAN}

\subsection{METODE PENDEKATAN}

Metode pendekatan pada penelitian ini bersifat deskriptif. Penelitian deskriptif adalah penelitian yang dilakukan untuk mengetahui nilai variabel 
Jurnal Ekonomi dan Perbankan Syariah

Vol. 5. No.1, April 2017: 95-113, ISSN (cet): 2355-1755 | ISSN (online): 2579-6437

103

mandiri, baik satu variabel atau lebih (independen) tanpa membuat perbandingan atau menghubungkan dengan variabel lain (Sugiyono 2006). Menurut (Indrianto 2009) Studi deskriptif menjelaskan karakteristik suatu fenomena yang dapat digunakan sebagai dasar pembuatan keputusan untuk memecahkan masalah-masalah bisnis.

\subsection{LOKASI PENELITIAN}

Dalam hal ini penulis termasuk dalam Tim peneliti dalam kegiatan sosialisasi SRG Tahun 2011 dan 2012 dan melakukan pengamatan secara langsung ke beberapa daerah lokasi penelitian seperti: Bogor wilayah Propinsi Jawa Barat, Pidie Jaya wilayah Propinsi Nangroe Aceh Darussalam. Banjarnegara dan Pekalongan wilayah Propinsi Jawa Tengah pada tahun 2011. Adapun tahun 2012 lokasi penelitian berada di Pidie wilayah Nangroe Aceh Darussalam, Serdang Bedagai, Simalungun, Tana Karo wilayah Sumatra Utara dan Masohi wilayah Propinsi Maluku.

\subsection{DATA DAN JENIS DATA}

Sumber data penelitian terdiri dari sumber data primer dan sumber data sekunder. Data primer diperoleh dari laporan kegiatan penelitian dan sosialisasi Sistem Resi Gudang tahun 2010-2012 yang diselenggarakan oleh Bappebti Kementerian Perdagangan Republik Indonesia. Kemudian data sekunder diperoleh dari Badan Pusat Statistik dan data dari kapubaten dalam angka yang menjadi daerah penelitian. Data sekunder lainnya diperoleh dari artikel, UU no. 9 tahun 2006, UU no. 9 tahun 2011, dan Surat Keputusan Kepala Bappebti.

Jenis data yang digunakan dalam penelitian ini adalah data subyek dan data dokumenter. Menurut (Indrianto 2009) Data subyek adalah jenis data penelitian berupa opini, sikap, pengalaman atau karakteristik dari seseorang atau sekelompok orang yang menjadi subyek penelitian. Adapun data dokumenter adalah jenis data penelitian yang antara lain berupa: faktur, jurnal, surat-surat, notulensi rapat, memo, atau dalam bentuk laporan program

\subsection{TEKNIK PENGUMPULAN DATA}

Teknik pengumpulan data yang digunakan dalam penelitian ini adalah:

1. Observasi

Teknik pengumpulan observasi digunakan untuk mengungkapkan masalah keadaan obyek penelitian. Dalam hal ini penulis mengadakan pengamatan terhadap obyek penelitian yaitu saat kunjungan acara sosialisasi Sistem Resi Gudang dilakukan di daerah-daerah.

2. Dokumentasi 
104 | Zulkarnain: Analisis Transaksi Resi Gudang dan Potensi Pengembangannya...

Data dokementasi diperoleh dengan cara mengakses dan mengumpulkan dokumen atau laporan yang bersumber dari pihakpihak yang berkaitan dengan penelitian, baik dari Bappebti ataupun adan Pusat Statistik yang diperoleh dari sumbernya di www.bps.go.id dan www.bappebti.go.id

3. Studi kepustakaan (Library research)

Studi pustaka dilakukan dengan menelaah buku-buku sumber, jurnal-jurnal, laporan penelitian yang sejenis serta dari website lembaga-lembaga yang berkaitan dan relevan dengan penelitian. Studi kepustakaan ini dilakukan untuk menambah teoritis yang berkaitan dengan judul yang diangkat dalam penelitian ini.

\subsection{TEKNIK ANALISIS DATA}

Dalam melakukan analisis penelitian ini, peneliti menggunakan teknik analisis asosiatif. Penelitian asosiatif adalah penelitian yang bertujuan untuk mengetahui hubungan dua variable atau lebih. (Sugiyono 2006)

Variabel yang digunakan dalam penelitian ini terbagi menjadi dua, yakni variabel terikat (dependent variabel) dan variabel bebas (independent variabel). Variabel terikat dalam penelitian ini adalah volume komoditi gabah pada transaksi resi gudang mulai tahun 2008 - 2013. Adapun variabel bebas dalam penelitian ini adalah volume produksi gabah, harga gabah, kadar air dan suku bunga, yang peneliti dapatkan datanya di Badan Pusat Statistik mulai tahun 2008 - 2013.

Data-data dari Faktor-faktor yang berpengaruh terhadap transaksi Resi Gudang akan diolah dan dianalisa menggunakan program spss 19.0 For Windows. Pada bagian ini akan dideskripsikan hasil analisa menggunakan data sekunder yang bersumber dari Badan Pusat Statistik dan Bappebti Kementrian Perdagangan Republik Indonesia.

Metode statistik yang digunakan dalam mengolah data adalah statistik non parametrik menggunakan alat analisis Korelasi Rank Spearman, hal ini diakibatkan data yang penulis dapatkan mengalami beberapa kondisi yang memungkinkan digunakannya metode statistik nonparametrik, antara lain: (Santoso 2010)

1. Untuk data yang tidak berdistribusi normal atau varians tidak sama, bisa dilakukan transformasi data ke logaritmik, akar dan sebagainya, lalu dilakukan normalitas dan varian sekali.

2. Jika jumlah data terlalu sedikit, bisa diusahakan penambahan data hingga memenuhi prosedur parametrik (sekitar 30 data atau lebih) sejauh penambahan data tidak membebani biaya dan masih relevan dengan tujuan penelitian.

3. Untuk data bertipe nominal atau ordinal, hal ini tidak bisa diubah, karena menyangkut 'nature' data. Mau tidak mau prosedur nonparametrik sangat dianjurkan untuk tipe data nominal dan ordinal. 
Jurnal Ekonomi dan Perbankan Syariah

Vol. 5. No.1, April 2017: 95-113, ISSN (cet): 2355-1755 | ISSN (online): 2579-6437

105

Sebelum dilakukan pengujian hipotesis peneliti akan melakukan uji asumsi klasik dengan melakukan uji normalitas hal ini dilakukan untuk menguji apakah variabel-variabel dalam model berdistribusi normal atau tidak. Menurut (Suliyanto 2011) model regresi yang baik adalah yang memiliki distribusi normal atau mendekati normal. Data yang tidak berdistribusi normal biasanya disebabkan oleh distribusi data yang tidak normal seperti adanya nilai ekstrem pada data yang diambil. Nilai ekstrem tersebut bisa disebabkan karena kesalahan dalam pengambilan sampel, kesalahan karena input data maupun karena karakteristik data tersebut jauh dari rata-rata.

\section{PEMBAHASAN}

\subsection{ANALISIS FAKTOR-FAKTOR YANG BERHUBUNGAN TERHADAP TRANSAKSI RESI GUDANG}

Analisis yang digunakan untuk menguji sejauh mana hubungan atau pengaruh yang ditimbulkan dari volume produksi gabah, harga gabah kering, kadar air dan suku bunga terhadap volume gabah dalam transaksi resi gudang maka digunakanlah analisa statistik non parametrik dengan alat uji hipotesis asosiatif.

Alat uji yang dipergunakan dalam penelitian ini adalah Korelasi Spearman Rank, hal ini dimaksudkan oleh penulis untuk mencari hubungan atau signifikansi hipotesis asosiatif bila masing-masing variabel berbentuk ordinal dan sampelnya kecil.

Data dalam variabel tersebut didapat dari Badan Pusat Statistik sejak tahun 2008 sampai dengan 2013 sebagaimana terdapat pada tabel 2 , hal ini dilakukan karena data yang lengkap belum bisa didapat saat penulis melakukan observasi di daerah penelitian.

Tabel 2. Data Rata-Rata Volume Produksi Gabah, Harga Gabah Kering,

Kadar Air dan Suku Bunga di Indonesia Tahun 2008 - 2013

\begin{tabular}{|l|l|l|l|l|l|}
\hline No & Tahun & $\begin{array}{c}\text { Volume } \\
\text { Produksi Gabah }\end{array}$ & $\begin{array}{c}\text { Harga Gabah Kering } \\
\text { Panen (Rp/Kg) }\end{array}$ & $\begin{array}{c}\text { Kadar Air } \\
\text { (Teknologi } \\
\text { Penyimpanan) }\end{array}$ & Suku Bunga \\
\hline 1 & 2013 & 70.866 .571 & $4.080,32$ & 18,64 & 6,48 \\
\hline 2 & 2012 & 69.056 .126 & $4.019,97$ & 18,63 & 5,77 \\
\hline 3 & 2011 & 65.756 .904 & $3.652,29$ & 18,72 & 6,58 \\
\hline 4 & 2010 & 66.469 .394 & $3.174,67$ & 18,73 & 6,50 \\
\hline 5 & 2009 & 64.398 .890 & $2.762,22$ & 18,69 & 7,15 \\
\hline 6 & 2008 & 60.325 .925 & $2.538,61$ & 19,10 & 9,5 \\
\hline
\end{tabular}

Sumber : Data Badan Pusat Statistik Diolah, 2014 
106 | Zulkarnain: Analisis Transaksi Resi Gudang dan Potensi Pengembangannya...

\subsection{ANALISIS UJI NORMALITAS DATA DENGAN KOLMOGOROV-SMIRNOV}

Sebelum data diolah dan dianalisis, data terlebih dahulu diuiji normalitas untuk mengetahui data terdistribusi normal atau tidak. Analisis ini dilakukan untuk membuktikan bahwa modelnya termasuk model yang baik karena telah memenuhi kriteria BLUE (Best Linear Unbiased Estimator).

Berikut merupakan hasil uji normalitas variabel volume produksi, harga gabah kering, kadar air dan suku bunga terhadap volume komoditi gabah dalam transaksi resi gudang.

Tabel 3. Hasil Uji Normalitas Data

\begin{tabular}{|ll|r|r|r|r|}
\hline & & Vol_Prod & Hrg_GK & K_Air & S_Bunga \\
\hline $\mathrm{N}$ & & 6 & 6 & 6 & 6 \\
Normal Parameters & & 6 & 6 & 6 \\
& Mean & 66145635.00 & 3371.3467 & 18.7517 & 6.9967 \\
& Std. Deviation & 3686034.966 & 648.91478 & .17543 & 1.30247 \\
Most Extreme Differences & Absolute & .151 & .175 & .382 & .292 \\
& Positive & .132 & .159 & .382 & .292 \\
& Negative & -.151 & -.175 & -.244 & -.179 \\
Kolmogorov-Smirnov Z & & .370 & .428 & .937 & .716 \\
Asymp. Sig. (2-tailed) & & .999 & .993 & .344 & .685 \\
\hline
\end{tabular}

a. Test distribution is Normal.

b. Calculated from data.

Sumber : data diolah

Suatu data dikatakan terdistribusi normal jika memiliki nilai signifikansi diatas 0,05 (>0,05). Dari gambar Kolmogorov-smirnoz Z test diatas dapat terlihat dibagian Asymp sig. (2-tailed) semua variabel memiliki nilai signifikansi diatas $0,05(>0,05)$. Jadi dapat disimpulkan bahwa data-data yang digunakan dalam penelitian ini terdistribusi normal karena semua variabel mempunyai signifikan diatas $0,05(>0,05)$, volume produksi 0,370 data harga gabah kering 0,428 data kadar air 0,937 dan data Suku Bunga 0,716 .

\subsection{HASIL UJI KORELASI RANK SPEARMAN}

Apakah terdapat korelasi antara volume produksi gabah, harga gabah, kadar air dan suku bunga terhadap volume gabah dalam transaksi resi gudang?, maka hipotesisnya adalah :

Ho = Tidak terdapat hubungan antara volume produksi gabah, harga gabah, kadar air dan suku bunga dengan volume gabah dalam transaksi resi gudang.

$\mathrm{Ha}=$ Terdapat hubungan antara volume produksi gabah, harga gabah, kadar air dan suku bunga dengan volume gabah dalam transaksi resi gudang. 
Jurnal Ekonomi dan Perbankan Syariah

Vol. 5. No.1, April 2017: 95-113, ISSN (cet): 2355-1755 | ISSN (online): 2579-6437

107

Tabel 4. Hasil Uji Korelasi Rank Spearman

Correlations

\begin{tabular}{|c|c|c|c|c|c|c|c|}
\hline & & & Vol_Prod & $\mathrm{Hrg} \mathrm{GK}$ & $K_{\text {_Air }}$ & S_Bunga & Yol_Gabah \\
\hline \multirow[t]{15}{*}{ Spearman's mo } & \multirow[t]{3}{*}{ Yol_Prod } & Correlation Coefficient & 1000 & $943^{10}$ & -714 & $-943^{112}$ & $886^{\circ}$ \\
\hline & & Sig (2-tailed) & & .005 & 111 & 905 & .019 \\
\hline & & N & 6 & 6 & 6 & 6 & 6 \\
\hline & \multirow[t]{3}{*}{$\mathrm{Hrg}_{2} \mathrm{GK}$} & Correlasion Coefficient & $943^{\prime \prime}$ & 1.000 & -771 & $-886^{x}$ & $.943^{\prime \prime}$ \\
\hline & & Sig. (2-tailed) & .005 & & .072 & .019 & .005 \\
\hline & & N & 6 & 6 & 6 & 6 & 6 \\
\hline & \multirow[t]{3}{*}{ K_Air } & Correlation Coefficient & -714 & -771 & 1000 & .771 & -600 \\
\hline & & Sig. (2-tailed) & 111 & .072 & & .072 & .208 \\
\hline & & N & 6 & 6 & 6 & 6 & 6 \\
\hline & \multirow[t]{3}{*}{ S_Bunga } & Correlation Coefficient & $-943^{\prime \prime \prime}$ & $-.886^{2}$ & 771 & 1000 & $-.829^{2}$ \\
\hline & & Sig. (2-tailed) & 005 & .019 & 072 & . & .042 \\
\hline & & N & 6 & 6 & 6 & 6 & 6 \\
\hline & \multirow[t]{3}{*}{ Yol_Gabah } & Correlabion Coefficient & $886^{7}$ & $943^{10}$ & -600 & $-829^{t}$ & 1.000 \\
\hline & & Sig. (2-tailed) & 019 & .005 & 208 & .042 & . \\
\hline & & $N$ & 6 & 6 & 6 & 6 & 6 \\
\hline
\end{tabular}

* Correlation is significant at the 0.01 level (2-tailedi.

* Correlation is significant at the 005 level (2-taled).

Sumber: data diolah

\subsection{HUBUNGAN VOLUME PRODUKSI GABAH TERHADAP VOLUME KOMODITI GABAH DALAM TRANSAKSI RESI GUDANG}

Berdasarkan tabel 4 terlihat bahwa berdasarkan hasil pengujian korelasi antara volume produksi gabah dengan volume komoditi gabah dalam transaksi resi gudang didapatkan nilai koefisien korelasi Rank Spearman sebesar 0,886 . Artinya besar nilai kekuatan korelasi antara volume produksi gabah dengan volume komoditi dalam transaksi resi gudang sebesar 0,886 . Nilai koefisien ini menurut (Sarwono 2006) tergolong kedalam hubungan sangat kuat. Itu berarti ada korelasi positif yang kuat dan searah, atau dengan kata lain kalau volume produksi gabah meningkat maka volume komoditi gabah dalam transaksi resi gudang akan meningkat pula, begitu juga sebaliknya.

Selain itu berdasarkan nilai signifikansi yang telah ditetapkan 0,05 hubungan antara volume produksi gabah dengan volume komoditi gabah dalam transaksi resi gudang signifikan karena nilai signifikansi kurang dari $0,05(0,019<0,05)$. Karena $p$-value kurang dari 0,05 maka H0 di tolak. Hal ini berarti hipotesis pertama diterima bahwa terdapat hubungan yang signifikan antara volume produksi gabah dengan volume komoditi gabah dalam transaksi resi gudang.

Semakin meningkat hasil panen petani tentunya akan semakin menambah kemungkinan untuk menyimpan sebagian komoditinya di gudang resi gudang yang secara tidak langsung akan meningkatkan transaksi resi gudang itu sendiri. Di dalam Tabel 4.11 terdapat data perkembangan volume 
dan nilai komoditi SRG dimana Komoditi gabah menjadi komoditi terbanyak sebesar 43.363,43 ton dibanding dengan komoditi lainnya dengan jumlah resi gudang yang terbit sebanyak 1.114 resi gudang.

\subsection{HUBUNGAN HARGA GABAH TERHADAP VOLUME KOMODITI GABAH DALAM TRANSAKSI RESI GUDANG.}

Berdasarkan tabel 4 terlihat bahwa berdasarkan hasil pengujian korelasi antara harga gabah dengan volume komoditi gabah dalam transaksi resi gudang didapatkan nilai koefisien korelasi Rank Spearman sebesar 0,943. Artinya besar nilai kekuatan korelasi antara volume produksi gabah dengan volume komoditi dalam transaksi resi gudang sebesar 0,943. Nilai koefisien ini menurut (Sarwono 2006) tergolong kedalam hubungan sangat kuat. Itu berarti ada korelasi positif yang kuat dan searah, atau dengan kata lain kalau harga gabah meningkat maka volume komoditi gabah dalam transaksi resi gudang akan meningkat pula, begitu juga sebaliknya.

Selain itu berdasarkan nilai signifikansi yang telah ditetapkan 0,05 hubungan antara harga gabah dengan volume komoditi gabah dalam transaksi resi gudang signifikan karena nilai signifikansi kurang dari 0,05 $(0,005<$ 0,05), karena $p$-value kurang dari 0,05 maka H0 di tolak. Hal ini berarti hipotesis kedua diterima bahwa terdapat hubungan yang signifikan antara harga gabah dengan volume komoditi gabah dalam transaksi resi gudang.

Para petani sangat mengkhawatirkan kebijakan intervensi harga gabah dan kebijakan operasi pasar beras yang dilakukan oleh pemerintah, sebab hal ini dapat menurunkan harga beras di pasaran yang berarti akan menurunkan transaksi resi gudang.

\subsection{HUBUNGAN KADAR AIR DENGAN VOLUME KOMODITI GABAH DALAM TRANSAKSI RESI GUDANG}

Berdasarkan tabel 4 terlihat bahwa berdasarkan hasil pengujian korelasi antara kadar air dengan volume komoditi gabah dalam transaksi resi gudang didapatkan nilai koefisien korelasi Rank Spearman sebesar -0,600. Artinya besar nilai kekuatan korelasi antara volume produksi gabah dengan volume komoditi dalam transaksi resi gudang sebesar 0,600. Nilai koefisien ini menurut (Sarwono 2006) tergolong ke dalam hubungan kuat. Hal ini berarti terdapat korelasi negatif yang menyatakan hubungan bersifat invers (kebalikan), atau dengan kata lain makin kecil prosentase kadar air maka volume komoditi gabah dalam transaksi resi gudang akan meningkat, begitu juga sebaliknya.

Selain itu berdasarkan nilai signifikansi yang telah ditetapkan 0,05 hubungan antara kadar air dengan volume komoditi gabah dalam transaksi resi gudang signifikan karena nilai signifikansi lebih besar dari 0,05 (0,208 > 0,05). Karena $p$-value lebih besar dari 0,05 maka $\mathrm{H} 0$ di tolak dan $\mathrm{H} 0$ di terima. Hal ini berarti hipotesis ketiga ditolak bahwa tidak terdapat hubungan yang signifikan antara kadar air dengan volume komoditi gabah dalam transaksi resi gudang. 
Jurnal Ekonomi dan Perbankan Syariah

Vol. 5. No.1, April 2017: 95-113, ISSN (cet): 2355-1755 | ISSN (online): 2579-6437 109

Hal ini berarti pula bahwa kadar air yang tinggi tidak akan mempengaruhi peningkatan volume komoditi gabah dalam transaksi resi gudang. Hal ini sangat bersesuaian dengan kondisi di lapangan dimana pada umumnya kadar air hasil panen para petani selalu diatas prosentase yang diinginkan oleh pengelola gudang dalam menjalankan Sistem Resi Gudang dengan ukuran maksimum kadar air yang bisa diterima dalam transaksi resi gudang maksimal adalah $14 \%$.

Perhitungan kadar air tersebut dilakukan tanpa menggunakan alat bantu, melainkan berdasarkan kebiasaan petani. Sementara itu kadar air yang dipersyaratkan untuk disimpan di dalam gudang sebesar $14 \%$, sehingga hasil panen dari para petani tersebut memerlukan pengeringan. Pengeringan dapat dilakukan dengan cara dijemur pada terik matahari atau pun dengan menggunakan mesin pengering. Oleh karena lantai jemur dan mesin pengering dalam gudang Sistem Resi Gudang tidak mencukupi untuk mengeringkan semua hasil panen padi yang hendak disimpan di dalam gudang, maka para petani diharapkan sudah mengeringkan hasil panennya hingga memenuhi persyaratan untuk disimpan di dalam gudang.

\subsection{HUBUNGAN SUKU BUNGA DENGAN VOLUME KOMODITI GABAH DALAM TRANSAKSI RESI GUDANG}

Berdasarkan tabel 4 terlihat bahwa berdasarkan hasil pengujian korelasi antara suku bunga dengan volume komoditi gabah dalam transaksi resi gudang didapatkan nilai koefisien korelasi Rank Spearman sebesar -0,829. Artinya besar nilai kekuatan korelasi antara volume produksi gabah dengan volume komoditi dalam transaksi resi gudang sebesar 0,829. Nilai koefisien ini menurut (Sarwono 2006) tergolong ke dalam hubungan sangat kuat. Hal ini berarti terdapat korelasi negatif yang menyatakan hubungan bersifat invers (kebalikan), atau dengan kata lain makin kecil suku bunga maka volume komoditi gabah dalam transaksi resi gudang akan meningkat, begitu juga sebaliknya.

Selain itu berdasarkan nilai signifikansi yang telah ditetapkan 0,05 hubungan antara kadar air dengan volume komoditi gabah dalam transaksi resi gudang signifikan karena nilai signifikansi lebih besar dari 0,05 $(0,042>$ 0,05). Karena $p$-value kurang dari 0,05 maka $\mathrm{HO}$ di tolak. Hal ini berarti hipotesis keempat diterima bahwa terdapat hubungan yang signifikan antara suku bunga dengan volume komoditi gabah dalam transaksi resi gudang.

Sistem Resi Gudang meningkatkan akses kredit Petani, Poktan, Gapoktan dan Koperasi Tani karena SRG memudahkan mereka untuk mendapatkan pinjaman atau pembiayaan dari Bank, dengan menyimpan komoditi mereka di gudang yang dapat digunakan sebagai agunan. Selain itu, dengan SRG Petani, Poktan, Gapoktan dan Koperasi Tani mudah untuk menjual hasil panen mereka (tidak perlu membawa fisik barang, cukup dengan membawa resi gudang). Serta SRG membuat Petani, Poktan, Gapoktan dan Koperasi Tani mendapatkan harga yang lebih baik dibandingkan mereka harus menjual hasil pertaniannya pada saat panen yang 
biasanya harga cenderung turun lebih baik mereka menyimpan barangnya di gudang dan mendapatkan pinjaman (uang) dari bank sambil menunggu harga yang lebih baik.

\section{SIMPULAN}

Berdasarkan hasil penelitian dan analisis data dari bab sebelumnya, maka diperoleh kesimpulan sebagai berikut :

1. Mekanisme penerbitan, pengalihan, penjaminan, dan penyelesaian transaksi Resi Gudang merupakan rangkaian kegiatan yang saling berkaitan dalam Sistem Resi Gudang (SRG), adapun surat bukti kepemilikan barang yang disimpan di Gudang diterbitkan oleh Pengelola Gudang yang telah mendapatkan persetujuan dari Bappebti. SRG berdasarkan UU No. 9 Tahun 2006 merupakan salah satu instrumen penting dan efektif dalam sistem pembiayaan perdagangan yang bertujuan untuk mendorong pembangunan bidang ekonomi, khususnya di sektor pertanian dalam rangka ketahanan pangan dan ekspor.

2. Melalui SRG, petani, kelompok tani (Poktan), gabungan kelompok tani (Gapoktan), dan koperasi dapat memperoleh kredit di bank hanya dengan menggunakan Resi Gudang sebagai bukti kepemilikan barang yang disimpan di gudang tanpa diperlukan jaminan atau fixed asset lainnya seperti tanah, rumah, kendaraan bermotor, dan sebagainya. Sehingga, diharapkan SRG dapat memberikan solusi pembiayaan khususnya bagi petani, poktan, Gapoktan dan koperasi yang umumnya menghadapi masalah keterbatasan akses pembiayaan dari perbankan serta terbatasnya jaminan atau agunan kredit.

3. Terdapat empat faktor yang berpengaruh terhadap transaksi resi gudang yaitu volume produksi gabah, harga gabah kering panen, kadar air dan suku bunga. Adapun pengaruh faktor-faktor tersebut terhadap transaksi resi gudang dapat dilihat berdasarkan hasil uji nonparametrik menggunakan uji korelasi Rank Spearman sebagai berikut:

1. Terdapat korelasi positif antara volume komoditi gabah dalam transaksi resi gudang dan volume produksi gabah sebesar 0,886 dengan tingkat signifikansi $(0,019)<(0,05)$ maka H0 di tolak. Hal ini berarti volume produksi gabah mempengaruhi volume komoditi gabah dalam transaksi resi gudang.

2. Terdapat korelasi positif pula antara variabel harga gabah dan volume komoditi gabah dalam transaksi resi gudang sebesar 0,943. Adapun tingkat signifikansinya $(0,005)<(0,05)$ maka H0 di tolak. Hal ini berarti harga gabah yang meningkat akan mempengaruhi peningkatan volume komoditi gabah dalam transaksi resi gudang.

3. Adapun variabel kadar air dengan volume komoditi gabah dalam transaksi resi gudang sebesar -0,600. Hal ini berarti terdapat korelasi negatif yang menyatakan hubungan bersifat invers (kebalikan), atau 
Jurnal Ekonomi dan Perbankan Syariah

Vol. 5. No.1, April 2017: 95-113, ISSN (cet): 2355-1755 | ISSN (online): 2579-6437

| 111

dengan kata lain makin kecil prosentase kadar air maka volume komoditi gabah dalam transaksi resi gudang akan meningkat, begitu juga sebaliknya. Tingkat signifikansinya $(0,208)>(0,05)$ maka H0 di terima. Hal ini berarti kadar air yang tinggi tidak akan mempengaruhi peningkatan volume komoditi gabah dalam transaksi resi gudang. Hal ini sangat bersesuain dengan kondisi di lapangan dimana pada umumnya kadar air hasil panen para petani selalu diatas prosentase yang diinginkan oleh pengelola gudang dalam menjalankan Sistem Resi Gudang dengan ukuran maksimum kadar air yang bisa diterima dalam transaksi resi gudang maksimal adalah $14 \%$.

4. Selanjutnya nilai korelasi suku bunga dan volume komoditi gabah dalam transaksi resi gudang sebesar - 0,829. Hal ini berarti semakin kecil suku bunga maka volume komoditi gabah dalam transaksi resi gudang akan meningkat, begitu juga sebaliknya. Tingkat signifikansinya $(0,042)<(0,05)$ maka H0 ditolak. Hal ini berarti suku bunga yang rendah akan mempengaruhi peningkatan volume komoditi gabah dalam transaksi resi gudang.

Sistem Resi Gudang tidak bertentangan dengan ilmu fiqh, karena Sistem Resi Gudang tidak dimaksudkan untuk menahan barang supaya terjadi kelangkaan sebagaimana yang dimaksud dalam pengertian ihtikar dalam ilmu fiqh. Sistem Resi Gudang mempunyai batas waktu penyimpanan maksimum sekitar 3 bulan hingga 4 bulan dan memungkinkan terjadi kegiatan penjualan yang menghasilkan keuntungan pada selisih harga sedikit lebih tinggi. Dari latar belakang masalah dan manfaat yang didapatkan dalam Sistem Resi Gudang ternyata banyak yang bersesuaian dengan prinsipprinsip ekonomi Islam. Sektor pertanian menjadi sektor yang sangat menentukan nasib jutaan penduduk. Kalau kondisi pertanian mengalami kemajuan dan perkembangan, maka tingkat kesejahteraan penduduk akan naik, namun jika sebaliknya, maka mereka akan terus dalam kemiskinan dan keterbelakangan, selalu menjadi obyek eksploitasi pihak-pihak tertentu.aspek menahan barang dengan maksud mempersulit masyarakat itu tidak terpenuhi dalam Sistem Resi Gudang. Untuk itu perlu dikembangkan skema-skema transaksi keuangannya ke dalam skema syariah dalam pengembangan sistem resi gudang ke depan yang terbebas dari suku bunga atau riba.

\section{DAFTAR PUSTAKA}

Afzalurrahman. (2000). Muhammad Sebagai Seorang Pedagang. Jakarta: Yayasan Swarna Bhumy.

Ahmad, Kholilul Rahman. (2004). Menjawab Kegelisahan NU. 
112 | Zulkarnain: Analisis Transaksi Resi Gudang dan Potensi Pengembangannya...

Ashari. (2011). Potensi dan Kendala Sistem Resi Gudang (SRG) untuk Mendukung Pembiayaan Usaha Pertanian Di Indonesia." Forum Penelitian Agro Ekonomi, 29(2), 129-143.

Ghozali, Imam. (2005). Aplikasi Analisis Multivariat dengan Program SPSS, edisi ketiga. Semarang: Badan Penerbit Universitas Diponogoro.

Ginting, Ramlan. (2008). Transaksi Bisnis dan Perbankan Internasional. Jakarta : Salemba Empat.

Indrianto, Nur. (2009). Metodologi Penelitian Bisnis. Yogyakarta: BPFE Fakustas Ekonomi UGM.

Kementerian Perdagangan Republik Indonesia. (2009). Himpunan Peraturan Di Bidang Sistem Resi Gudang Jilid I. Jakarta: Bappebti.

Kementerian Perdagangan Republik Indonesia. (2011). Panduan Pelaksanaan Sistem Resi Gudang. Jakarta: Bappebti.

Khalil, Jafril. (2010). Jihad Ekonomi Islam. Jakarta: Gramata Publishing.

Kuntari, Arif R. Permana \& Yulita. (2006). Selayang Pandang UU Sistem Resi Gudang. Buletin Hukum Perbankan \& Kebanksentralan, 4(2), 78 .

Mansoori, Muhammad Tahir. (2010). Kaidah-Kaidah Fiqih Keuangan dan Transaksi Bisnis. Bogor: Ulil Albaab Institute.

P, Ryan Navis Eka. (2010). Analisis Undang-Undang No.9 Tahun 2006 Tentang Sistem Resi Gudang Berdasarkan Prespektif Hukum Ekonomi. November 7, 2010. http://ryannavisekaf.wordpress.com (accessed Maret 9, 2012).

Pembiayaan, Pusat. (2006). Pedoman Umum Sistem Tunda Jual Komoditas Pertanian. Jakarta: Pusat Pembiayaan Pertanian, Departemen Pertanian.

Purnamasari, Irma Devita. (2011). Hukum Jaminan Perbankan. Bandung: Kaifa.

Purwoko, Sunu Widi. (2011). Catatan Hukum Seputar Perjanjian Kredit Dan Jaminan. Jakarta: Nine Season Communication.

Sadarestuwati. (2008). "Pentingnya Sistem Resi Gudang bagi Petani." Makalah disampaikan pada Seminar Nasional Sistem Resi Gudang, Pengembangan Alternatif Pembiayaan melalui Sistem Resi Gudang. Hotel Borobudur, November 4, 2008.

Santoso, Singgih. (2010). Statistik Nonparametrik. Jakarta: PT. Elex Media Komputindo.

Sarwono, Jonathan. (2006). Mengenal Korelasi. Yogyakarta: Universitas Negeri Yogyakarta. 
Jurnal Ekonomi dan Perbankan Syariah

Vol. 5. No.1, April 2017: 95-113, ISSN (cet): 2355-1755 | ISSN (online): 2579-6437

| 113

Serfianto, Iswi Hariyani dan R. (2010). Resi Gudang Sebagai Jaminan Kredit \& Alat Perdagangan . Jakarta: Sinar Grafika.

Statistik, Badan Pusat. (2013a). Hasil Sensus Pertanian 2013 (Angka Sementara). Berita Resmi Statistik, Jakarta: Badan Pusat Statistik.

Statistik, Badan Pusat. (2013b). Profil Kemiskinan Di Indonesia Maret 2013. Berita Resmi Statistik, Jakarta: Badan Pusat Statisti.

Sugiyono. (2006). Metode Penelitian Kuantitatif Kualitatif dan $R \& D$. Bandung: Alfabeta.

Suliyanto. (2011). Ekonometrika Terapan: Teori \& Aplikasi dengan SPSS. Yogyakarta: CV. Andi offset.

Suparmin. (2007). Intervensi Pemerintah (BULOG) Dalam Stabilisasi Harga Gabah Petani. Konpernas Perhepi, 26-31.

Syafi'i, Muhamad Antonio. (1999). Bank Syariah: Wacana Ulama Dan Cendekiawan. Jakarta: Bank Indonesia dan Tazkia institute.

Umar, Husein. (2003). Metode Riset Bisnis. Jakarta: PT. Gramedia Pustaka Utama.

P3EI UII Yogyakarta. (2009). Ekonomi Islam. Jakarta: Rajawali Press. 
114 | Zulkarnain: Analisis Transaksi Resi Gudang dan Potensi Pengembangannya... 